\title{
国頭マージ地帯における懸濁態窒素の形態と沈殿池での除去率
}

\author{
仲村渠将 $1 \cdot$ 吉永安俊 $2 \cdot$ 酒井一人 2 .島袋理央 3
}

\section{Form of Particulate Nitrogen in a Kunigami Maaji Soil Area and its Trap Efficiency in an Ideal Tank}

\author{
Tamotsu Nakandakari ${ }^{1}$, Anshun Yoshinaga $^{2}$, Kazuhito Sakai $^{2}$, and Rio Shimabukuro ${ }^{3}$
}

\begin{abstract}
Deposition in a sedimentation tank may become important resource because it contains soil and nutrients. The purpose of this study was to examine the form characteristics of particulate nitrogen as related to its settling and particulate nitrogen trap efficiency in an ideal settling tank. For the purpose of this study, observing suspended soil particles with a digital microscope, measuring particulate nitrogen concentrations classified by the suspended soil particle size, and calculating trap efficiency based on the clarification theory of an ideal settling basin were conducted. As a result, it was found that the particulate nitrogen concentration of the suspended soil classified as fine sand was higher than that of silt and clay. It was also found that particulate nitrogen was nitrogen as a constituent of the organic matter in a micro aggregate, so that it was relatively easy to settle. The results show that particulate nitrogen is removed easier than suspended soil, so that its trap efficiency in sedimentation tanks is higher than that of suspended soil.
\end{abstract}

Keywords: Red soil runoff; Particulate nitrogen; Micro aggregate; Soil organic matter; Settling velocity distribution

1 はじめに

沖縄地方では，降雨時の畑地の土㙵侵食に起因した水環 境の污濁を防ぐため沈砂池などの赤土等流出防止対策が 実施されている (沖縄県農林水産部，2005)。畑地周辺の 水環境への赤土流出を防止することが赤土等流出防止対 策の本来の目的である。しかしながら，たとえば仲村渠 ら (2009)による沈砂池における眯濁態栄養成分の貯留を 考慮すると, 今後, 沈砂池の貯留物は重要な資源になり うる. 懸濁態栄養成分のような貯留資源の利用を考える 場合, 沈砂池の貯留機能は沈砂池の多面的機能として新 たに評価される．そのためには沈砂池の貯留効果を把握 することが重要になる。

懸濁態栄養成分としては懸濁態窒素と懸濁態りンが重 要であるといえる。懸濁態リンの場合，土粒子に固定さ れた形態，アルミニウムや鉄との化合物である難溶性沈 殿物としての形態が主であると考えられ，沈砂池におけ る懸濁態リンの貯留は浮遊土の動態に大きく依存すると 思われることから，沈砂池での貯留に関する動態をある 程度把握しやすい。一方, 䀣濁態窒素の形態は懸濁態り ンほど明らかではない，おそらく有機物としての形態が 主であると思われるが，水の密度より大きくないと沈砂 池の貯水中で沈降しないことから, 有機物のみから形成 された形態だけでは沈砂池における懸濁態窒素の貯留を 説明しにくい，そのため，とくに懸濁態窒素の貯留を検 討するためには，沈降しうるような形態的特徵を把握す ることが重要になる.

1琉球大学農学部助教, Assistant Professor, Faculty of Agriculture, University of the Ryukyus, 1 Senbaru, Nishihara, Okinawa 903-0213, Japan (Corresponding Author) E-mail:zhunai@ agr.u-ryukyu.ac.jp

2琉球大学農学部教授, Professor, Faculty of Agriculture, University of the Ryukyus, 1 Senbaru, Nishihara, Okinawa 903-0213, Japan

3 琉球大学大学院農学研究科修士課程, Graduate Student, Graduate school of Agriculture, University of the Ryukyus, 1 Senbaru, Nishihara, Okinawa 903-0213, Japan
沈砂池の設計には理想沈殿池の理論 (Camp, 1946) が用 いられている (沖縄県農林水産部, 1995)。浮遊土の除去 率の計算はその設計理論に従っている. 設計業務が簡素 になるように考慮すれば，理想沈殿池の理論を用いて懸 濁態窒素の除去率を計算するほうがよい。懸濁態窒素の 除去率は理想沈殿池の理論を用いて計算することができ るといえるが，これまでにそのような事例は報告されて いない。これは懸濁態窒素の形態があまり明らかではな いことに加えて, 除去率の計算に必要な懸濁態窒素の粒 径分布あるいは沈降速度分布が把握されていないためで あると考えられる。

そこで本研究では, 懸濁態窒素に対する沈砂池の貯留 効果を把握するため, 沈砂池に流入する浮遊土を顕微鏡 で観察し，また懸濁態窒素濃度を粒径別に測定すること によって懸濁態窒素の形態を調べた。また, 懸濁態窒素の 沈降速度分布を実験的に把握し, 理想沈殿池の理論を用 いて沈砂池の懸濁態窒素の除去率を調べた。さらに，懸 濁態窒素の除去率と浮遊土の除去率を比較して, 懸濁態 窒素の形態がその除去率に与える影響を検討した。なお， 沖縄地方の国頭マージ地帯を対象地域とした。

\section{2 方法}

\section{1 懸濁態窒素の形態的特徵の把握方法}

2.1.1 デジタルマイクロスコープによる浮遊土の形態観察 沈砂池の流入口で採水した懸濁試料水をスライドグラス に滴下し，デシケータ内で静かに乾燥させる。 スライド グラス表面に乾固した浮遊土をデジタルマイクロスコー プ (KEYENCE 製，VHX-1000)で観察する．別に，過酸 化水素水を加えて加熱して有機物を分解させた懸濁試料 水についても同様に観察する。 


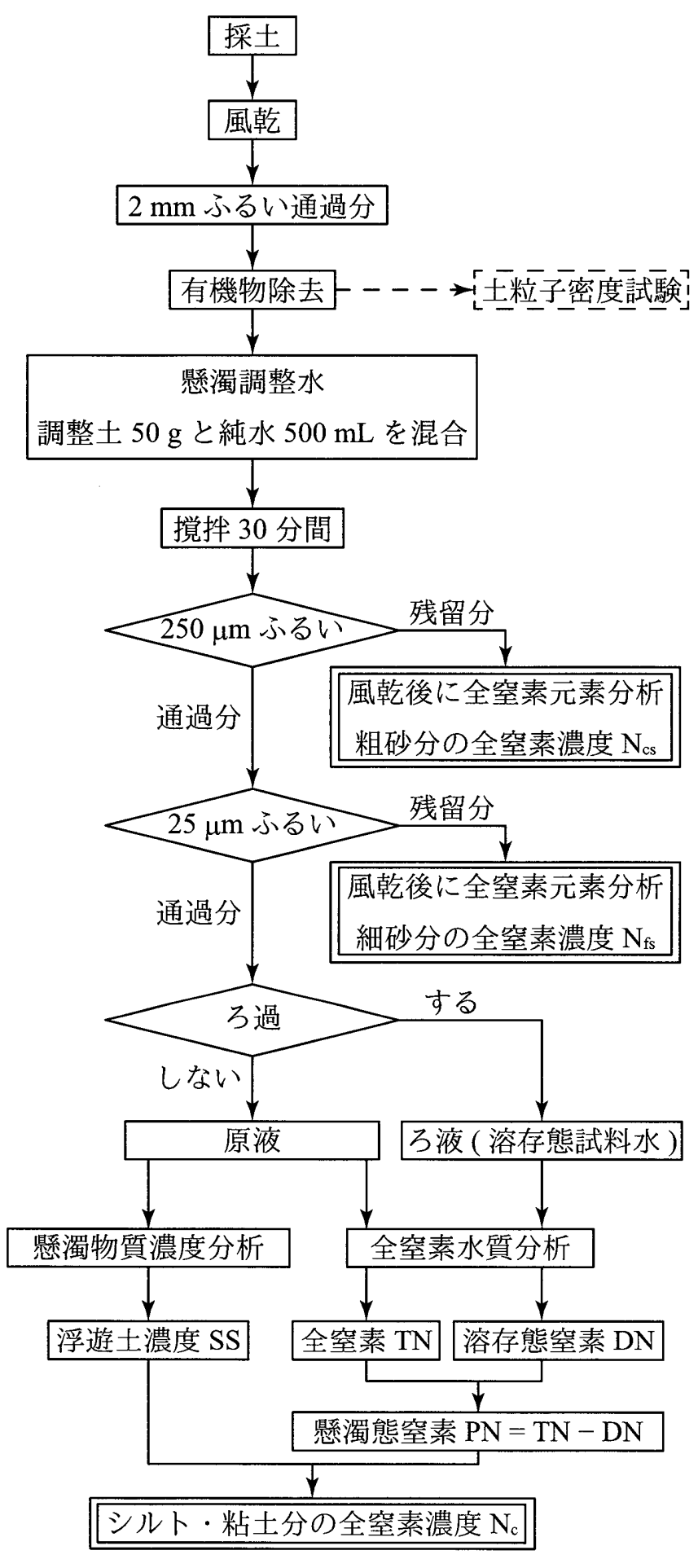

図 1: 粒径別粗濁態窒素濃度の測定方法

有機物非分解浮遊土と有機物分解浮遊土のデジタルマイ クロスコープ画像を比較して懸濁態窒素の形態を調べる.

\subsection{2 粒径別懸濁態窒素濃度の測定}

図 1 に粒径別懸濁態窒素濃度の測定方法をフローチャー トで示した。 また，実験に用いる試料土の採土地点とその 特徵を表 1 に示した。浮遊土は排水路内の流れで沈砂池 まで輸送されてくる過程で水と接触するため, 浮遊土の 表面に付着した溶解性の窒素成分の一部は水中に溶出す
表 1: 試料土の採土地点とその特徵

\begin{tabular}{|c|c|c|}
\hline 試料名 & 採土地点 & 特徵 \\
\hline 東村 1 & $\begin{array}{l}\text { N } 26^{\circ} 38^{\prime} 0.6^{\prime \prime} \\
\text { E } 128^{\circ} 10^{\prime} 12.0^{\prime \prime} \\
\text { GL } 44 \mathrm{~m}\end{array}$ & $\begin{array}{l}\text { 国頭マージ土壌 } \\
\text { サトウキビ畑 } \\
\text { 土粒子密度 } \\
\quad \rho_{s 1}=2.621 \mathrm{Mg} \cdot \mathrm{m}^{-3}\end{array}$ \\
\hline 東村 2 & $\begin{array}{l}\text { N } 26^{\circ} 38^{\prime} 15.7^{\prime \prime} \\
\text { E } 128^{\circ} 14^{\prime} 19.0^{\prime \prime} \\
\text { GL } 117 \mathrm{~m}\end{array}$ & $\begin{array}{l}\text { 国頭マージ土壌 } \\
\text { 切土斜面 } \\
\text { 植生なし } \\
\text { 土粒子密度 } \\
\quad \rho_{s 2}=2.585 \mathrm{Mg} \cdot \mathrm{m}^{-3}\end{array}$ \\
\hline 嵐山 & $\begin{array}{l}\text { N } 26^{\circ} 38^{\prime} 17.2^{\prime \prime} \\
\text { E } 127^{\circ} 59^{\prime} 26.3^{\prime \prime} \\
\text { GL } 111 \mathrm{~m}\end{array}$ & $\begin{array}{l}\text { 国頭マージ土壌 } \\
\text { サトウキビ畑 } \\
\text { 土粒子密度 } \\
\quad \rho_{s 3}=2.725 \mathrm{Mg} \cdot \mathrm{m}^{-3}\end{array}$ \\
\hline
\end{tabular}

ると考えられる．このような現象を再現するため，懸濁調 整水を作った後, $150 \mathrm{rpm}$ の回転擋找翼を使って $1000 \mathrm{~mL}$ のメスシリンダー内で一様に擋找する.

本研究では国際土堙学会の粒径区分を参考にして, 浮遊 土を粗砂分 $(250 \mu \mathrm{m}$ から $2 \mathrm{~mm}$ まで $)$, 細砂分 $(25 \mu \mathrm{m}$ から $250 \mu \mathrm{m}$ まで) およびシルト・粘土分 ( $25 \mu \mathrm{m}$ 末満) に区分し ている. 図 1 のフローチャートからわかるように, 粗砂分 と細砂分はそれぞれ $250 \mu \mathrm{m}$ ふるいと $25 \mu \mathrm{m}$ ふるいの残留 分であるからこれらは固形試料として得られる。固形試 料である粗砂分と細砂分に含まれる窒素成分は懸濁態窒 素である．粗砂分と細砂分の全窒素濃度の測定には全窒 素・全炭素測定装置 (住化分析センタ一製, SUMIGRAPH NC-220F) を用いる. 粗砂分および細砂分の風乾試料を乳 鉢ですりつぶし，その約 $1 \mathrm{~g}$ を供試する.

$25 \mu \mathrm{m}$ ふるい通過分として得られるシルト・粘土分は懸 濁した液体試料に含まれている.シルト・粘土分に含まれ る窒素成分がシルト・粘土分としての懸濁態窒素になる が，その濃度を直接に定量するのは容易ではない．そこ で図 1 に示すように，懸濁した液体試料の原液の全窒素 濃度 TN からろ液の溶存態窒素濃度 DN を差し引いて懸 濁態公素濃度 PNを求め, さらに懸濁した液体試料の原液 の浮遊土濃度 SS で PN を除してシルト・粘土分の全窒素 濃度を求める。なお, 本研究ではろ液の全窒素濃度を溶 存態窒素濃度と呼んでいる。液体試料の原液とろ液の全 窒素濃度の測定には多項目迅速水質分析計 $(\mathrm{HACH}$ 社製, DR2500) を用いる. 懸濁物質濃度分析などでは公称孔径 $1 \mu \mathrm{m}$ のグラスファイバーフィルター (MILLIPORE 社製, AP40 タイプ) を使用して吸引ろ過 (JIS K 0102) を行う.

\subsection{3 理想沈殿池を想定した眯濁態窒素の除去率}

浄水場の沈殿池の設計 (たとえば，丹保憲仁・小笠原紘一, 1985a ; 土木学会, 2004a)にも用いられている理想沈殿池 の理論 $(\mathrm{Camp}, 1946)$ を適用して，表 1 に示した 3 つの試 料土ごとに㴵濁態窒素の除去率を計算する。計算に必要 な資料は浮遊土の粒径分布, 粒径別䀣濁態窒素濃度, 沈 降速度式および理想沈殿池の水面面積と流量である。以 下，これらの資料について説明する。

沖縄地方の畑地带の場合，沈砂池に流入する浮遊土の 粒径はおよそ $100 \mu \mathrm{m}$ 未満の範囲に分布することが報告さ れている (仲村渠ら，2007).このことは沈砂池で除去対 象となる浮遊土は細砂分やシルト・粘土分であることを示 
している.このような現場条件を考慮するため, $106 \mu \mathrm{m}$ ふるい通過土の粒径分布をレーザ一回折式粒度分布測定 装置 (島津製作所製, SALD-200V ER) で測定する。土の 粒度試験方法 (JIS A 1204) に従って供試試料を作成する。

浮遊土の粒径分布に前項での測定結果となる粒径別懸 濁態窒素濃度を乗じて懸濁態窒素の粒径別質量を求め, 各 粒径の質量が全質量に占める割合として懸濁態窒素の粒 径分布を求める. なお，ここでいう懸濁態窒素の粒径と はなんらかの形態の窒素成分が付着・結合した状態にあ る浮遊土の粒径である。

条件に応じた種々の沈降速度式が提案されているが，沖 縄県の沈砂池の設計指針 (沖縄県農林水産部, 1995) に従 い式 (1)に示したストークス式を用いる.

$$
w=\frac{g\left(\rho_{p}-\rho_{f}\right)}{18 \mu} d^{2}
$$

ここに, $w$ : 沈降速度 $\left(\mathrm{m} \cdot \mathrm{s}^{-1}\right), g$ :重力加速度 $\left(\mathrm{m} \cdot \mathrm{s}^{-2}\right)$, $\rho_{p}$ :粒子の密度 $\left(\mathrm{kg} \cdot \mathrm{m}^{-3}\right), \rho_{f}$ : 流体の密度 $\left(\mathrm{kg} \cdot \mathrm{m}^{-3}\right), \mu$ :粘 性係数 $(\mathrm{Pa} \cdot \mathrm{s}), d$ :球形粒子の直径 $(\mathrm{m})$ である.

式 (1) の粒子密度には表 1 の土粒子密度, その他の各 定数には表 2 の值を用いる。式 (1) を用いて粒径分布の 粒径を沈降速度に変換して沈降速度分布を得る。

仲村渠ら (2009) の現地調査結果との比較を考慮し て, その調査対象となった沈砂池 (除去領域の水面面積 $\left.2154 \mathrm{~m}^{2}\right)$ の条件に基づいて想定する理想沈殿池の水面面 積を $\mathrm{A}=2000 \mathrm{~m}^{2}$, 流量を $\mathrm{Q}=1 \mathrm{~m}^{3} \cdot \mathrm{s}^{-1}$ に定める.した がって, 表面負荷率は $\mathrm{w}_{0}=\mathrm{Q} / \mathrm{A}=5 \times 10^{-4} \mathrm{~m} \cdot \mathrm{s}^{-1}$ になる.

懸濁態窒素の沈降速度分布と表面負荷率を用いて想定 した理想沈殿池における懸濁態窒素の除去率を計算する. 除去率の計算方法については土木学会 $(2004 b)$ および丹 保・小笠原 $(1985 b)$ に従っている.

比較のため, 浮遊土の除去率と表 1 の土粒子密度より 小さい粒子密度 $\left(2.0,1.5\right.$ および $\left.1.0 \mathrm{Mg} \cdot \mathrm{m}^{-3}\right)$ を用いた場 合の懸濁態窒素の除去率を同様にして計算する。

\section{表 2: 沈降速度式の各定数值}

\begin{tabular}{cc}
\hline 定数 & 值 \\
\hline$g$ & $9.8 \mathrm{~m} \cdot \mathrm{s}^{-2}$ \\
$\rho_{f} \dagger$ & $998.2 \mathrm{~kg} \cdot \mathrm{m}^{-3}$ \\
$\mu \dagger$ & $1.002 \times 10^{-3} \mathrm{~Pa} \cdot \mathrm{s}$ \\
\hline †水温を $20^{\circ} \mathrm{C}$ した。
\end{tabular}

\section{3 結果および考察}

\section{1 懸濁態窒素の形態的特徵}

\subsection{1 デジタルマイクロスコープ画像による形態把握}

図 2 に浮遊土のデジタルマイクロスコープ画像の一例を 示した。上段の (a) 有機物非分解浮遊土の画像には大小 さまざまな粒径の粒子が写されている。この画像の場合， 中央部には長径が約 $400 \mu \mathrm{m}$ の浮遊土が見られる. 画像が 幾分ぼやけているためわかりにくいが，この浮遊土はよ り細かな一次粒子が集合して形成されている二次粒子で ある。本論文では示していないその他の画像でも同じ様 子が観察された。

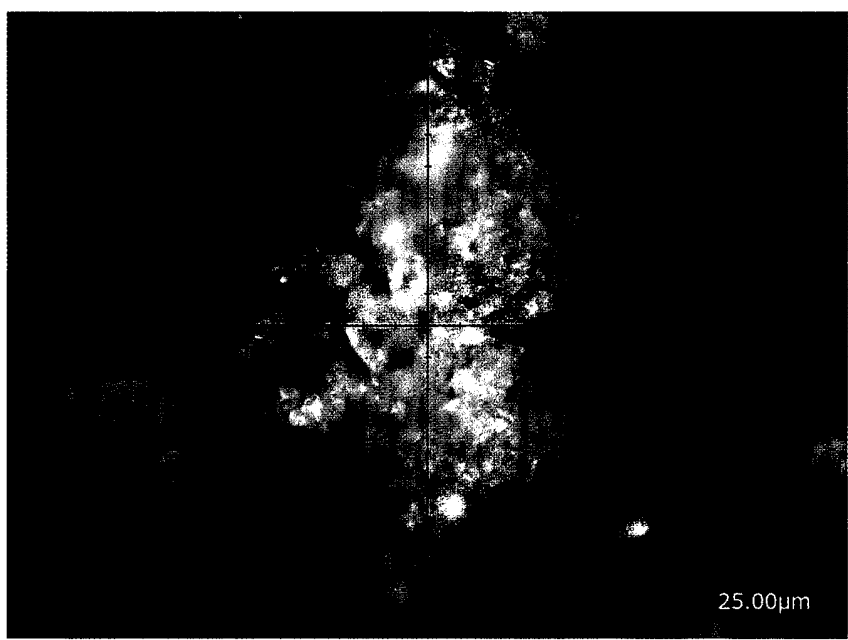

(a) 有機物非分解浮遊士

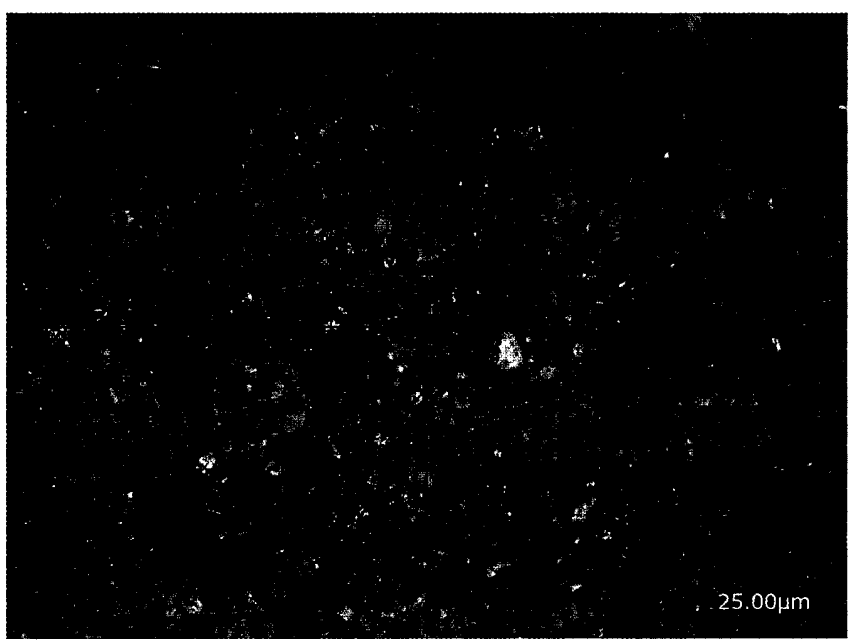

(b) 有機物分解浮遊土

図 2: 浮遊土のデジタルマイクロスコープ画像

画像 (a)に見られる二次粒子の形成には一次粒子間の集 合作用が必要である。畑土壌の構成物を考慮すれば，その ような集合作用は腐植物質などの有機物が担うと考えら れる. 図 2 下段の (b) 有機物分解浮遊土の画像は二次粒子 の形成に有機物が関与していることを示している．画像 (b)には一次粒子だけが写されている。つまり，画像 (b) は浮遊土に含まれる有機物が失われると一次粒子は二次 粒子を形成できないことを示している，すなわち，有機 物は二次粒子としての浮遊土の形成に必要な物質である.

土壌中における窒素成分の主な形態が有機物であるこ とを考慮すれば，二次粒子を形成させている有機物には 窒素成分が含まれているといえる。

以上のことから，賏濁態窒素の形態には植物残椬など の有機物としての形態は当然のこととして，画像 (a)に見 られる二次粒子に含まれる有機物としての形態も存在す ることが認められる。

二次粒子の密度は二次粒子に占める有機物の量に左右 されるから，二次粒子の密度は水の密度より小さいとこ 
ろから大きいところまでの範囲に分布すると考えられる. 例えば，画像 (a)に見られる二次粒子は無機鉱物と思われ る一次粒子が密に集合しているため, その二次粒子の密 度は水の密度より大きいと考えられる，ゆえに，条件が整 えばこの二次粒子は水中で沈降できる。このことは有機 物の密度が水の密度より小さいとしても，画像 (a)のよう に有機物が二次粒子の一部として存在する場合には，水 中で沈降できる懸濁態窒素が存在することを示している.

画像 (b)より，一次粒子の粒径は大きくても数十 $\mu \mathrm{m}$ で あると思われる．したがって，とくに浮遊土の細砂分は 二次粒子がその主体であることが推測され，少なくとも 細砂分には懸濁態窒素成分が含まれていることが示唆さ れる。

\subsection{2 粒径別懸濁態窒素濃度による形態把握}

粒径別懸濁態窒素濃度の測定結果を表 3 に示した。濃度 は単位質量の浮遊土に含まれる窒素の総質量として示さ れる．懸濁態窒素濃度を粒径区分別に比較すると，どの 粒径区分の場合でも東村 1 と風山は東村 2 より大きかつ た. 表 1 に示したとおり, 東村 2 の試料土は切土斜面の土 である。この切土斜面には植生がなく，また施肥もされ ないため窒素供給源はほとんど存在しない。一方，東村 1 と風山の試料土はサトウキビ畑の土壌であるため, 作物 残椬や施肥による窒素供給がある。このような窒素供給 源の有無が試料土ごとの懸濁態窒素濃度に影響している と考えられる。

すべての試料土について，細砂分の懸濁態窒素濃度は 粗砂分とシルト・粘土分より大きいことがわかった。䯚 濁態窒素は浮遊土の細砂分に比較的多く含まれていると いえる.この結果は前項の考察を裏付ける結果である.

土壌の構成物は互いの接触を避けられないはずである から，とくに二次粒子を形成させている有機物について は，それだけが単独で土壌中に存在するような状況を考 えにくい，二次粒子を形成させるような有機物は必然的 に二次粒子の一部となり，細砂分や粗砂分に比較的多く 含まれるようになると考えられる.

\section{2 理想沈殿池を想定した懸濁態窒素の除去率}

\subsection{1 懸濁態窒素の沈降速度分布}

図 3 に試料土の $106 \mu \mathrm{m}$ ふるい通過分の粒度分布曲線を示 した。東村 2 はシルト・粘土分を比較的多く含んでいた。 図 3 の粒度分布曲線, 表 3 の粒径別懸濁態窒素濃度およ び式 (1)の沈降速度式を用いて䀣濁態窒素の沈降速度分 布を求めた結果を図 4 に破線で示した。比較のため，浮 遊土の沈降速度分布を併せて実線で示した。

粒子密度が小さくなると沈降速度が小さくなるため, 図 4 下段側の小さい粒子密度が用いられた沈降速度分布 曲線は上段側よりも左方へシフトしている。粒子密度を 水の密度に最も近くした $\rho_{p}=1.0 \mathrm{Mg} \cdot \mathrm{m}^{-3}$ の場合, 沈降 速度分布曲線は表面負荷率 $w_{0}=5 \times 10^{-4} \mathrm{~m} \cdot \mathrm{s}^{-1}$ よりも小 さい範囲にあり，多くの浮遊土が沈降除去しにくい状態 で存在するようになっているといえる.

粒径がシルト・粘土分から細砂分に変化するところで 懸濁態窒素と浮遊土の沈降速度分布曲線が交差し, その 交点より沈降速度が大きい範囲，つまり細砂分の沈降速 度範囲では懸濁態窒素の沈降速度分布曲線のほうが上側 に位置する特徵が認められる。これは細砂分の懸濁態窒 素濃度がシルト・粘土分より大きいことが原因である。ま
表 3: 粒径別懸濁態窒素濃度 (単位 : $\mathrm{mg} / \mathrm{kg}$ )

\begin{tabular}{crrc}
\hline 試料 & 粗砂分 & 細砂分 & シルト・粘土分 \\
\hline 東村 1 & 46 & 376 & 318 \\
東村 2 & 0 & 33 & 13 \\
風山 & 1043 & 1323 & 236
\end{tabular}

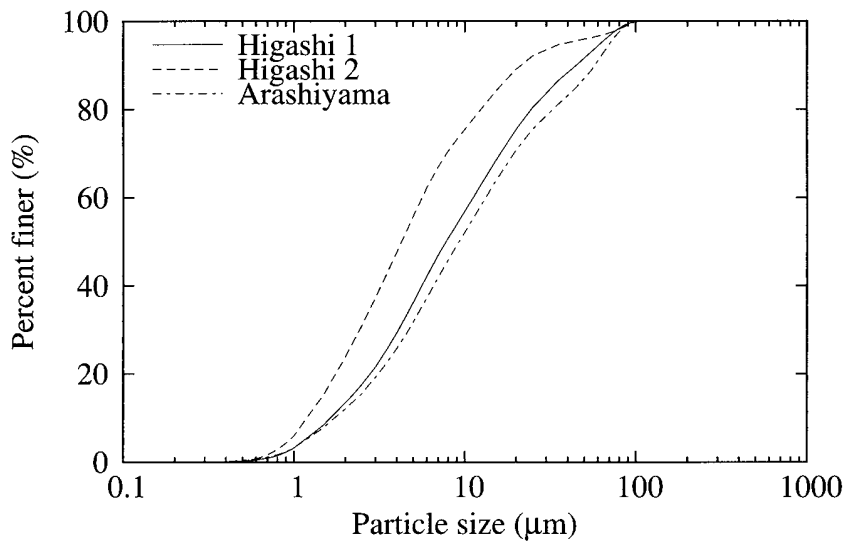

図 3: 試料土の $106 \mu \mathrm{m}$ ふるい通過分の粒度分布曲線

た, 粒子密度 $\rho_{p}=1.0 \mathrm{Mg} \cdot \mathrm{m}^{-3}$ の場合を除いて, その交 点の沈降速度が表面負荷率付近になっている特徴も認め られる。これらの特徵から, 懸濁態窒素にはその沈降速 度が表面負荷率より大きいものが浮遊土よりも大きい割 合で存在することがわかる.したがって, 懸濁態窒素は浮 遊土よりも沈降除去されやすい性質をしているといえる.

細砂分の沈降速度範囲における懸濁態窒素と浮遊土の 沈降速度分布曲線の間隔には試料土ごとの違いがある。嵐 山の場合，他よりも間隔が大きい. また，東村 1 と東村 2 を比較すると, 粒径別懸濁態窒素濃度が小さい東村 2 の ほうがその間隔は大きい。これらのような関係には細砂 分とシルト・粘土分の懸濁態公素濃度との比が関与して おり，その比が大きいと懸濁態窒素と浮遊土の沈降速度 分布曲線の間隔も大きくなり, 懸濁態窒素が浮遊土より も沈降除去されやすい性質がより顕著になる.

図 2 に示した浮遊土の形態からして異なる大きさの粒 子密度が混在しているのは明らかである。たとえば二次 粒子の場合, 粒径が同じでも有機物含有量が異なればそ の粒子密度も異なる。本論文では除去効果を定性的に把 握することに主眼を置き，浮遊土の形態によらず粒子密 度を一様とする場合のみを検討している，異なる大きさの 粒子密度を混在させた場合については今後の課題とする.

\subsection{2 懸濁態窒素の除去率}

図 4 に示した風山の沈降速度分布を例にして，粒子密度 $\rho_{p}=\rho_{s}$ のときの除去率を求めた結果を図 5 に示した. 沈 降速度分布曲線を実線で，除去率曲線を破線で示してい る。見やすくするため, 除去率曲線と沈降速度軸の間を グレーに着色した。 なお, 本研究では, 沈降速度分布が表 す頻度のうち，理想沈殿池で除去可能な頻度に相当する 部分を表す曲線を除去率曲線と呼んでいる。除去率曲線 が示す頻度 (グレーの着色部分) を合計した值が除去率と 

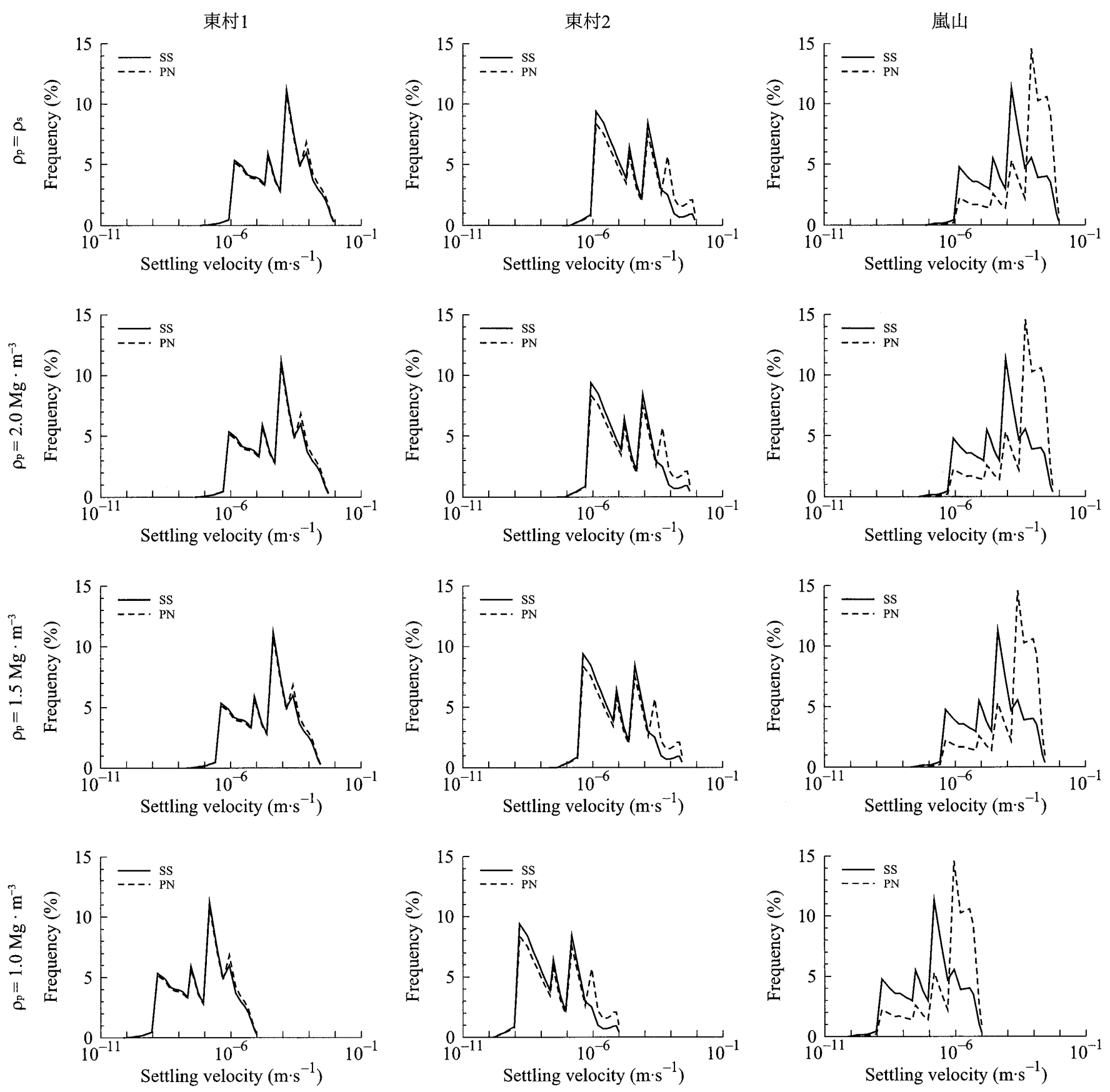

図 4: 沈降速度分布

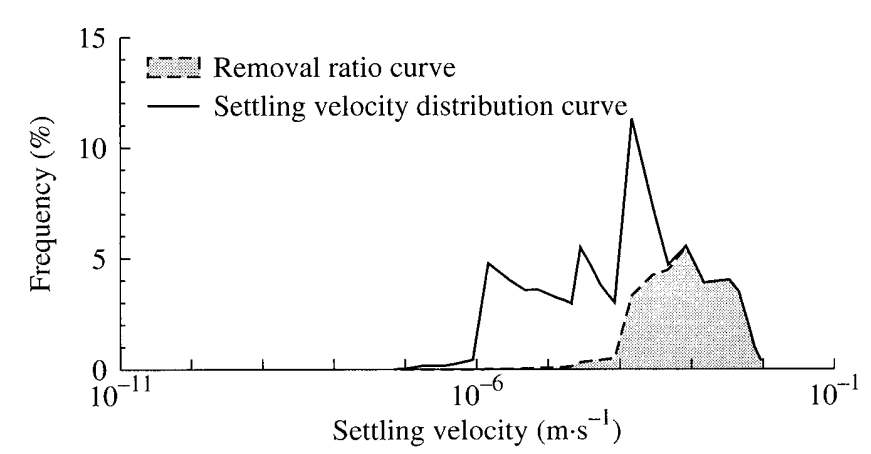

(a) 浮遊土の除去率曲線

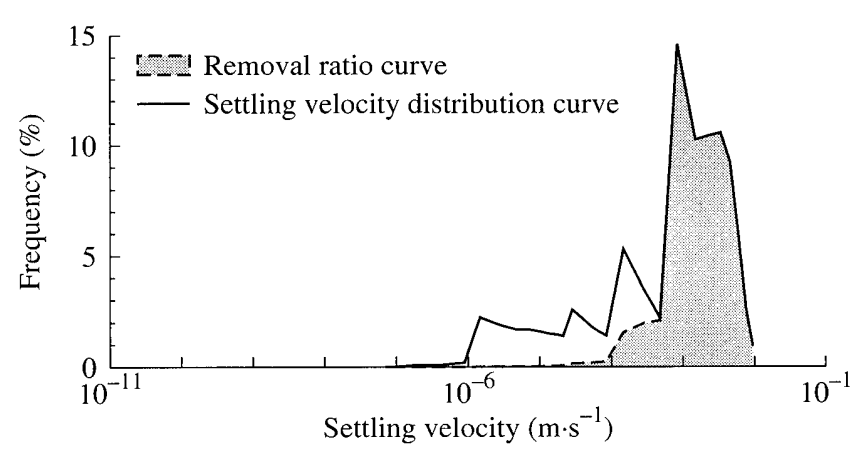

(b) 懸濁態窒素の除去率曲線

図 5: 除去率曲線 (試料土: 嵐山, 粒子密度 : $\rho_{p}=\rho_{s}$ ) 
表 4: 浮遊土と䀣濁態窒素の除去率 (単位: \%)

\begin{tabular}{|c|c|c|c|c|c|c|}
\hline \multirow{2}{*}{$\begin{array}{c}\rho_{d} \\
\left(\mathrm{Mg} \cdot \mathrm{m}^{-3}\right)\end{array}$} & \multicolumn{2}{|c|}{ 東村 1} & \multicolumn{2}{|c|}{ 東村 2} & \multicolumn{2}{|c|}{ 風山 } \\
\hline & SS & $\mathrm{PN}$ & SS & $\mathrm{PN}$ & SS & $\mathrm{PN}$ \\
\hline$\rho_{s}$ & 33.59 & 35.88 & 17.98 & 26.87 & 39.10 & 71.41 \\
\hline 2.0 & 28.13 & 30.59 & 14.21 & 23.45 & 32.87 & 68.24 \\
\hline 1.5 & 20.44 & 22.57 & 9.69 & 17.57 & 25.45 & 57.82 \\
\hline 1.0 & 0.12 & 0.14 & 0.07 & 0.14 & 0.17 & 0.41 \\
\hline
\end{tabular}

なり，図 5 に示した例の場合，浮遊土の除去率は $39.10 \%$, 懸濁態窒素の除去率は $71.41 \%$ あっった。その他の試料土 および粒子密度の場合についても図 5 と同じ解析を行い, その結果を表 4 にまとめた。

表 4 より, 解析条件下における懸濁態窒素の除去率は $0.14 \%$ から $71.41 \%$ までの幅広い範囲に分布し, 粒子密度 および試料土の違いに応じて変化した。懸濁態窒素の除 去率の大小関係はどの粒子密度の場合でも嵐山>東村 $1>$ 東村 2 となった。この除去率の大小関係は粒径別懸濁態窒 素濃度の大小関係と同じであり, 粒径別懸濁態窒素濃度 の大きさは懸濁態窒素の除去率に影響しているといえる。

粒子密度 $\rho_{p}=1.0 \mathrm{Mg} \cdot \mathrm{m}^{-3}$ の場合, 懸濁態窒素の除去 率は極端に小さく，ほとんど除去されないといえる.

懸濁態窒素と浮遊土の除去率を試料土別に比較すると, どの試料土の場合でも懸濁態窒素の除去率は浮遊士の除 去率よりも大きいことがわかる．前節で考察したとおり， 細砂分の懸濁態窒素濃度が比較的大きいことなどにより， 懸濁態窒素が浮遊土よりも沈降除去されやすい性質をし ているためであると考えられる。

仲村渠ら (2009) はひとつの現地観測の結果, 眯濁態窒 素の除去率 93\%, 浮遊土の除去率 70\%であったと報告し, 本研究と同様に懸濁態窒素の除去率は浮遊土の除去率よ りも大きかったとする結果を示している. 本研究の考察 からすると, その現地観測結果についても懸濁態窒素の 形態と粒径別懸濁態窒素濃度が関与したためではないか と推察される。

4 おわりに

本研究では沖縄地方の国頭マージ地带を対象地域として, 懸濁態窒素に対する沈砂池の貯留効果を把握するため, 沈 砂池に流入する浮遊土を顕微鏡で観察し，また懸濁態窒 素濃度を粒径別に測定することによって懸濁態窒素の形態
を調べた。さらに，懸濁態窒素の沈降速度分布を実験的 に把握し, 理想沈殿池を想定した懸濁態窒素の除去率を 計算した。

その結果, 懸濁態窒素は浮遊土の二次粒子の構成成分 として存在することによって，沈降できる形態をしてい ることがわかった。 また, 細砂分の懸濁態窒素濃度がシ ルト・粘土分のそれよりも大きいため, 懸濁態窒素は浮 遊土よりも沈降除去されやすい性質をしていると考えら れた。理想沈殿池を想定した場合, 眯濁態窒素の除去率 は浮遊土の除去率よりも大きくなり, 既往の研究結果と 一致する結果が得られた。

今後の課題は沈降速度の計算において異なる大きさの 粒子密度を混在させた場合を検討することである.

引用文献

[1] Camp, T. R. (1946): Sedimentation and the design of settling tanks, Trans. ASCE, 111, pp. 895-958.

[2] 土木学会 (2004a): 環境工学公式・モデル・数值集, pp. 19-20.

[3] 土木学会 (2004b) : 環境工学公式.モデル・数值集, p. 18.

[4] 仲村渠将·吉永安俊・酒井一人 秋吉康弘 - 大澤和敏 (2007): 沈砂池における浮遊土砂流出に関する現地観測, 農業土木 学会論文集, 249 , pp. 47-53.

[5] 仲村渠将. 吉永安俊 - 酒井一人 (2009): 沈砂池での浮遊土 砂と富栄養化成分の流入出と削減に関する現地調査, 日本 雨水資源化システム学会誌, 15(1), pp. 1-7.

[6] 沖縄県農林水産部 (1995) : 土地改良事業における赤土流出 防止対策指針, pp. 32-34.

[7] 沖縄県農林水産部 (2005) : 水質保全対策事業 (耕土流出防 止型) 計画設計の手引き, p. 40.

[8] 丹保憲仁・小笠原紘一 (1985a) : 浄水の技術一安全な飲 み水をつくるために一，技報堂, pp. 60-74.

[9] 丹保憲仁 - 小笠原紘一 $(1985 \mathrm{~b})$ : 浄水の技術一一安全な飲 み水をつくるために一，技報堂, pp. 286-288.

この論文の公開の質疑または討議は 2012 年 12 月 31 日 まで受付けます. 